\title{
Non-traumatic Page kidney
}

\author{
Seda Ozbek, Ali Sami Kivrak, Cengiz Erol, Mustafa Koplay
}

Department of Radiology, Selcuk University, Faculty of Medicine, Konya, Turkey

\section{Correspondence to}

Dr Seda Ozbek

dsadr@hotmail.com
To cite: Ozbek S, Kivrak AS, Erol C, et al. BMJ Case Rep Published online: [please include Day Month Year] doi:10.1136/bcr-2013009135

\section{DESCRIPTION}

A 59-year-old male patient with a previous diagnosis of prostate cancer presented to the emergency department with left-sided abdominal pain. Physical examination was unremarkable except for high blood pressure $(190 / 115 \mathrm{~mm} \mathrm{Hg})$. There was no history of hypertension before admission. The patient was afebrile, he had no respiratory distress. Abdomen was soft and no rigidity or mass was present with palpation. The patient underwent abdominal CT scan which revealed left subcapsular renal haematoma. The thickest part of the subcapsular haematoma measured $31 \mathrm{~mm}$. A reduction in contrast uptake in the parenchymal portion of the affected kidney due to compression effect of haematoma was noted in CT images (figure 1A-C).

Page kidney is a rare condition resulting in hypertension secondary to renal compression by a subcapsular haematoma, tumour or cyst. External compression of the renal parenchyma results in hypoperfusion and activation of the renin-angiotensin-aldesterone axis. ${ }^{1}$ Page kidneys occurring in association with traumatic events such as motor vehicle accidents, sport injuries and renal interventions have been reported in the literature. ${ }^{2}$ Recently, Smyth et al ${ }^{2}$ reported non-trauma associated cases occurred due to native kidney biopsies, ruptured renal cyst, hypernephroma or renovascular diseases. Our patient only had a history of prostate surgery 2 years ago and no recent history of trauma. In the past, definitive management of Page kidney was radical nephrectomy or surgery. However, most recent reports present a trend towards minimal invasive procedures such as percutaneus drainage of haematoma, endoscopic interventions and other preventive techniques. ${ }^{3}$ The age of the haematoma is important for the choice of treatment. Haematomas less than 3 weeks old usually resolve spontaneously. But percutaneous drainage is usually unsuccessful and nephrectomy or capsulectomy are necessary in the cases of organised late haematomas. ${ }^{1}$ In our case, arterial hypertension is successfully taken under control with ACE inhibitor and diuretic treatment. Ultrasound follow-up revealed decrease in the size of haematoma. No further interventions or surgery were needed. Also Page kidney is a rare condition, it should be considered in the differential diagnosis of secondary arterial hypertension. Early diagnosis allows a chance to medical therapy.

\section{Learning points}

- Page kidney is an important cause of hyper-reninemeic hypertension that should be included in the differential diagnosis of secondary hypertension.

- Ultrasound and/or cross-sectional imaging are valuable in the diagnosis and follow-up.

- The age of the haematoma is important for the choice of treatment procedures range from medical therapy to percutaneous drainage to surgery. Early diagnosis allows a chance to medical therapy.

Acknowledgements SO participated in diagnosis and writing. ASK participated in diagnosis, CE in diagnosis and MK in writing and selecting images.

Competing interests None.

Patient consent Obtained.

Provenance and peer review Not commissioned; externally peer reviewed.

\section{REFERENCES}

1 Babel N, Sakpal SV, Chamberlain RS. The Page kidney phenomenon secondary to a traumatic fall. Eur J Emerg Med 2010;17:24-6.

2 Smyth A, Collins CS, Thorsteinsdottir B, et al. Page kidney: etiology, renal function outcomes and risk for future hypertension. J Clin Hypertens 2012;14:216-21.

3 Dopson SJ, Jayakumar S, Velez JC. Page kidney as a rare cause of hypertension: case report and review of the literature. Am J Kidney Dis 2009:54:334-9. 
Copyright 2013 BMJ Publishing Group. All rights reserved. For permission to reuse any of this content visit http://group.bmj.com/group/rights-licensing/permissions.

BMJ Case Report Fellows may re-use this article for personal use and teaching without any further permission.

Become a Fellow of BMJ Case Reports today and you can:

- Submit as many cases as you like

- Enjoy fast sympathetic peer review and rapid publication of accepted articles

- Access all the published articles

- Re-use any of the published material for personal use and teaching without further permission

For information on Institutional Fellowships contact consortiasales@bmjgroup.com

Visit casereports.bmj.com for more articles like this and to become a Fellow 